\title{
Teaching and learning process for mathematization activities: The case of solving maximum and minimum problems
}

\author{
Al Jupri*, Dian Usdiyana, Ririn Sispiyati \\ Department of Mathematics Education, Universitas Pendidikan Indonesia, Indonesia \\ *Corresponding author: aljupri@upi.edu
}

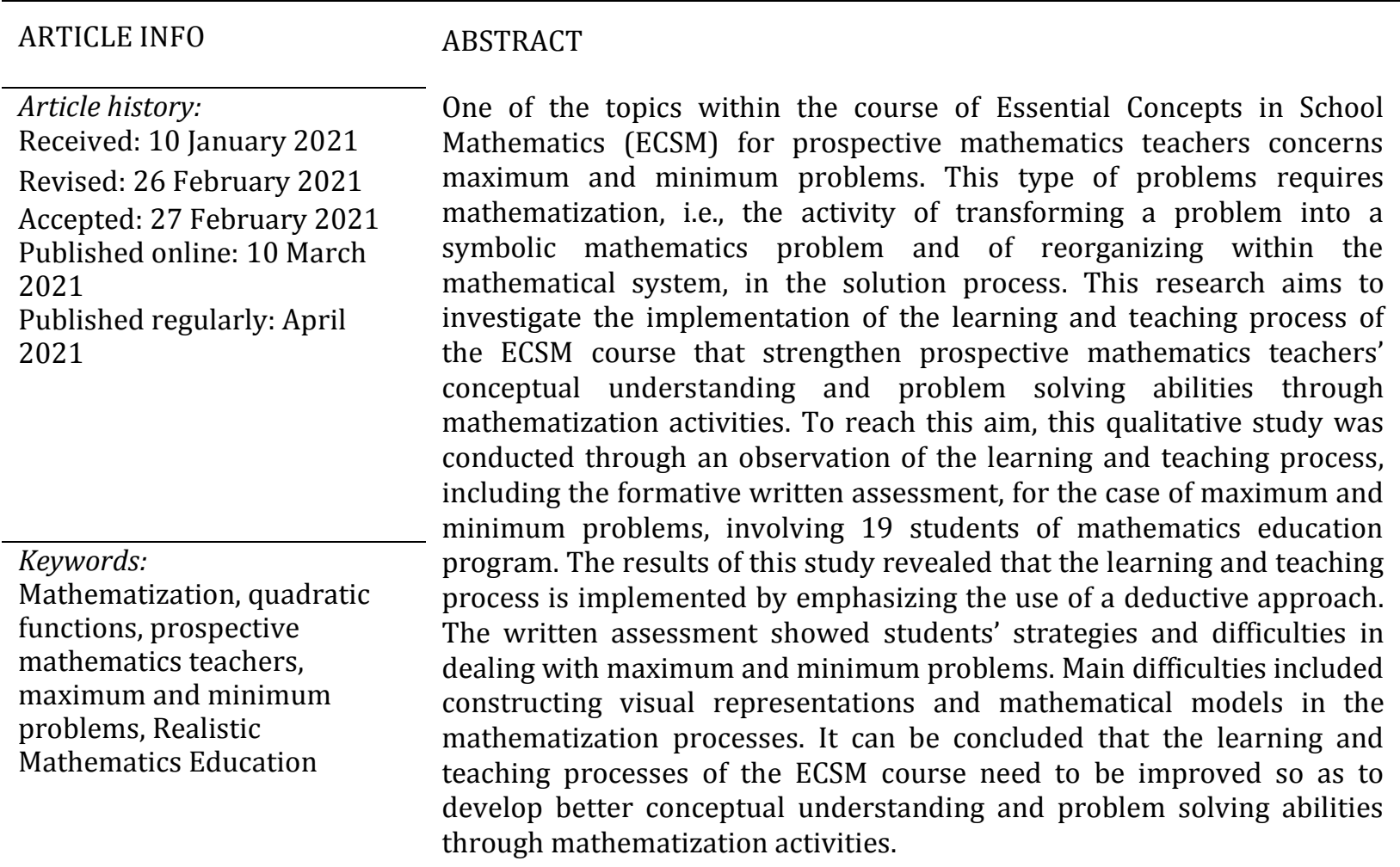

(C)2021 Universitas Muhammadiyah Surakarta

\section{Introduction}

One of students' difficulties in learning mathematics concerns solving word problems (Jupri \& Drijvers, 2016; Verschaffel et al., 2020). This difficulty is encountered by not only school students, but also mathematics education students as prospective mathematics teachers over the world (Bukova-Güzel, 2011; Osana \& Royea, 2011; Yilmaz \& Tekin-Dede, $\underline{2016}$ ), including in Indonesia (Jupri \& Rosjanuardi, 2020; Jupri \& Syaodih, 2016). Main difficulties in solving word problems include, for instance, translating problems into mathematical symbolic problems; visualizing the verbal text into diagrams, graphs, or tables; constructing mathematical models; and solving symbolic problems (Bukova-Güzel, 2011; Jupri \& Drijvers, 2016; Jupri, 2017). The activity of translating a word problem into a symbolic mathematical problem and vice versa, as well as solving the problem within the

To cite this article:

Jupri, A., Usdiyana, D., \& Sispiyati, R. (2021). Teaching and learning process for mathematization activities: The case of solving maximum and minimum problems. JRAMathEdu (Journal of Research and Advances in Mathematics Education), 6(2), 100-110. https://doi.org/10.23917/jramathedu.v6i2.13263 
world of mathematics, according to the theory of Realistic Mathematic Education (RME), is called mathematization (Freudenthal, 1991; Van den Heuvel-Panhuzen \& Drijvers, 2020; Van den Heuvel-Panhizen, 2003). This mathematization process is considered indispensable in a problem solving process, and should be acquired by prospective mathematics teachers.

One of the courses for students of prospective mathematics teachers for strengthening conceptual understanding and problem solving skills-which includes mathematization activities-is so-called Essential Concepts in School Mathematics (ECSM) course. One of the topics given in the course concerns word problems on maximum and minimum problems that require mathematization (Chapman, 2006; Freudenthal, 1991; Gravemeijer \& Doorman, 1999; Van den Heuvel-Panhuizen, 2003). Concerning this ECSM course we wonder how the learning and teaching process be implemented so as to strengthen students' conceptual understanding and problem solving skills, particularly the ability of mathematization.

The investigation of the learning and teaching for mathematization activities for prospective mathematics teachers can be carried out for instance through an observation of the teaching and learning process, particularly for the case of solving word problems related to maximum and minimum problems. Previous studies showed that this investigative study in Indonesian context is important yet to certain extent is quite rare (Jupri \& Rosjanuardi, 2020; Rizta \& Antari, 2019). Taking this issue into account, this research aims to investigate the implementation of the learning and teaching process of the ECSM course and its impact towards prospective mathematics teachers' conceptual understanding and problem solving abilities in mathematization activities.

\section{Theoretical Framework}

Theoretical frameworks used for this study include types of teaching approaches and the perspective of mathematization from the Realistic Mathematics Education theory (De Lange, 2006; Doorman \& Gravemeijer, 2009; Van den Heuvel-Panhuizen \& Drijvers, 2020). Concerning the types of teaching and learning approaches, in general there are two approaches: inductive and deductive (Prince \& Felder, 2006). The deductive approach in the teaching and learning process applies deductive thinking, i.e., thinking from general to more specific cases (Ndemo et al., 2017; Prince \& Felder, 2006). Therefore, teaching and learning steps in the deductive approach subsequently include explaining concepts, definitions, and principles; using these concepts, definitions and principles in solving exemplified problems; providing exercises and classroom discussion for students; and conducting an individual written test.

The inductive approach in the teaching and learning process applies inductive thinking, i.e., thinking from specific cases to a more general case (Ndemo et al., 2017; Prince \& Felder, 2006). Therefore, teaching and learning steps in the inductive approach subsequently include posing a specific problem for an investigation process; constructing conjectures, principles, concepts, or formulas through solving the problem; applying the concepts, principles, or formulas to solve similar problems; and drawing general conclusions based on the learning and teaching process.

Regarding mathematization, this term refers to an activity of transforming a problem into a mathematical symbolic model and vice versa, as well as of reorganizing the model within the world of mathematics (De Lange, 2006; Freudenthal, 1991; Treffers, 1987; Van den Heuvel-Panhuizen \& Drijvers, 2020). The mathematization cyclic process, for instance in the context of solving maximum or minimum realistic problems, is carried out by a 
student as follows: It starts with comprehending a word problem usually with a real world context; next, the student needs to identify relevant mathematics and to reorganize the problem into a mathematical model within the mathematical world; the mathematical model is then solved by using relevant mathematical procedures, principles, or formulas; and finally, the solution is reinterpreted into the initial context of the problem (De Lange, 2006). This mathematization cycle is depicted in Figure 1.

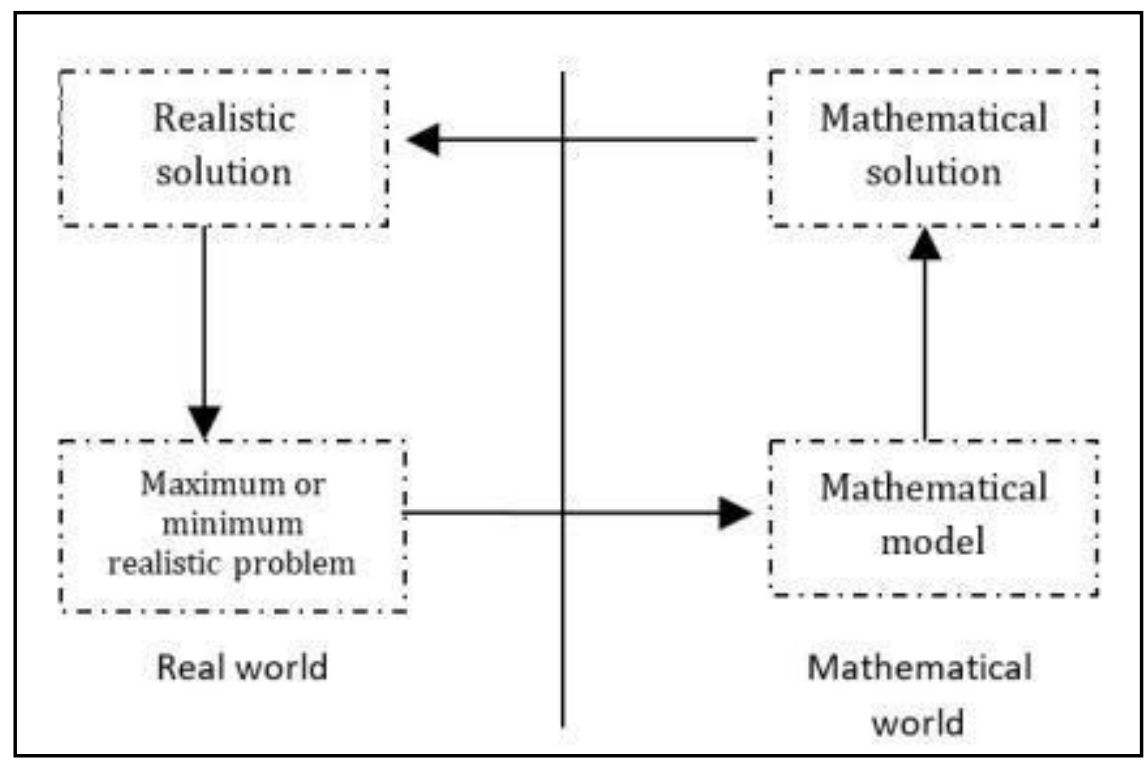

Figure 1. The mathematization cycle (Based on De Lange, 2006, p.17)

\section{Research Methods}

To investigate the teaching and learning process of the Essential Concepts in School Mathematics (ECSM) course for prospective mathematics teachers, we carried out a qualitative study in the form of a classroom observation. The classroom observation, for the case of the topic of maximum and minimum problems, consisted of two phases. In the first phase we conducted an online observation of the teaching and learning process (via zoom) involving 19 mathematics education students in one of state universities in Bandung. The observation lasted for 80 minutes. In this observation, using an observation sheet, we noted the teaching and learning steps, mathematical topics addressed in the teaching and learning process, the maximum and minimum problems given to students, and the interaction between students and the lecturer. In the second phase, we observed an individual written test on solving a maximum or minimum problem requiring the mathematization process, which lasted for 20 minutes. After the test, each student should upload his or her answer sheet in a Google-classroom. From the lecturer's information, maximum or minimum problems given to students during the learning process and in the written test were taken and adapted from Indonesian school mathematics textbooks. These textbooks have been reviewed by mathematics and mathematics education experts. Also, the lecturer selected the problems carefully for his lesson. Therefore, the validity of the test instrument was theoretically validated.

Data that we collected from the classroom observation included data of observation on the learning and teaching process in general, field notes concerning the sequence of the 
teaching and learning process, a lecture note in the form of a power point presentation, and students' written work which were downloaded from the Google-classroom platform.

In data analysis, the data on the learning and teaching process were analyzed using the framework of types of teaching and learning approaches; and the data on mathematics problems and students' written work were analyzed using the perspective of mathematization - which comes from the theory of Realistic Mathematics Education (De Lange, 2006; Van den Heuvel-Panhuizen \& Drijvers, 2020; Van den Heuvel-Panhuizen, 2003). In this analysis, we classified the learning and teaching process and its corresponding characteristics in terms of inductive or deductive approach; and we characterized students' strategies and difficulties in dealing with maximum and minimum problems according to the mathematization perspective.

\section{Results and Discussion}

This section describes the results of two phases of the classroom observation: the teaching and learning process for the case of solving maximum and minimum problems; and the result of corresponding written test. The first phase is mainly interpreted according to the framework of types of teaching and learning approaches; and the second phase is mainly analyzed with the mathematization perspective.

\section{The teaching and learning process for the case of solving maximum and minimum problems}

The mathematics topic observed from the course of Essential Concepts in School Mathematics (ECSM) concerns solving maximum and minimum word problems. The process of the teaching and learning was started by the lecturer through reminding students about concepts, principles, and formulas related to quadratic functions. For instance, students were reminded that a quadratic function $y=f(x)=$ 档 $x^{2}+b x+c$, where $a \neq 0$ has a minimum or maximum value $\left(b^{2}-4 a c\right) /(-4 a)$ when $x=-b / 2 a$. Next, the lecturer informed that these concepts, principles, and formulas can be applied to solve relevant maximum or minimum problems, which are usually in the form of word problems that need the process of translation into mathematical models.

As examples on how to apply the quadratic function concepts, principles, and formulas in solving maximum or minimum problems, the lecturer gave two problems shown in Figure 2. Figure 2(a) shows a minimum problem and Figure 2(b) shows a maximum problem. Solution to the Problem 1 in Figure 2(a) was explained clearly by the lecturer which is shown in Figure 3. During the explanation, for every step of solution, the lecturer posed relevant questions to students and would continue writing the step of the solution if students provided relevant responses. In other words, the explanation process was combined with question and answer activities to ensure that the students actively participate in the teaching and learning process. A difficult part for students during the questions and answers was about constructing a mathematical model from the given word problem. When discussing this part, it took time and demanded an extra effort from the lecturer. In addition to provide the explanation as shown in Figure 3, the lecturer also provided another strategy for determining the value of $x$ so that the quadratic function $f(x)=x^{2}-8 x+32$ has a minimum value, i.e., by rewriting this formula into $f(x)=$ $(x-4)^{2}+16$. This function will have a minimum value if $(x-4)^{2}=0$, which is equivalent to $x=4$. Therefore, it is concluded that the minimum value of $f(x)$ is 16 .

For the case of the Problem 2 in Figure 2(b), students were given time and opportunity to solve it first independently as an exercise before doing a classroom 
discussion. Next, their solutions were discussed under the guidance of the lecturer. Figure 4 shows an example of student work (rewritten here) for the Problem 2 during the classroom discussion. For the case of this task, students need to know not only basic knowledge in geometry, but also fundamental concepts in the analytical geometry, particularly about the equation of a straight line. Therefore, the process of constructing a mathematical model and solving the model (the mathematization process) needs these geometric concepts and principles. After guiding the discussion and drawing conclusions, the lecturer provided an individual written test. During the test, which lasted for 20 minutes, students were required to write down their solutions and explanation on their own answer sheets. An extra time for about ten minutes was given to provide an opportunity to students to scan the answer sheets and to upload them in the GoogleClassroom.

Problem 1. Let $P Q R S$ be a square as shown below.

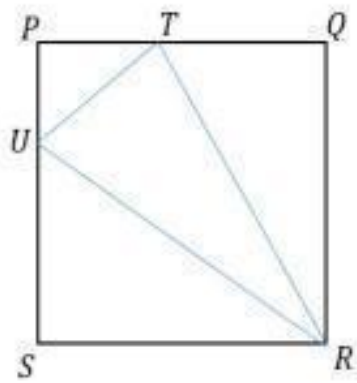

If $P Q=8 \mathrm{~cm}, S U=2 P T$, then find $P T$ such that the area of triangle $T R U$ is minimum. Then, find the minimum area for the triangle $T R U$.

(a)

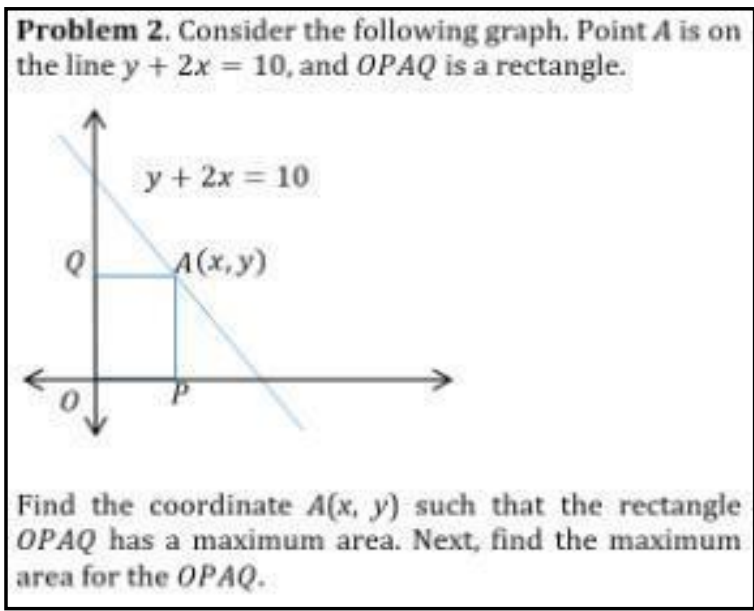

(b)

Figure 2. Problems in the teaching and learning process: (a) minimum problem, (b) maximum problem

$$
\begin{aligned}
& \text { Let } P T=x \text {, so } S U=2 x \text {. Next, consider } \\
& \text { the figure below. } \\
& \text { S-2x } \\
& \begin{array}{l}
\begin{aligned}
\text { Area TRU } & =\text { Area PQRS - Area } U P T-\text { Area URS - Area RQT. } \\
\qquad & =8 \times 8-\frac{1}{2} x(8-2 x)-\frac{1}{2} \cdot 8 \cdot 2 x-\frac{1}{2} \cdot 8 \cdot(8-x) . \\
& =64-\left(4 x-x^{2}\right)-8 x-32+4 x . \\
& =x^{2}-8 x+32 .
\end{aligned} \\
\text { The area of } T R U \text { will be minimum if } x=-\frac{(-8)}{2(1)}=4 . \\
\text { The minimum area of } T R U=4^{2}-8(4)+32=16 . \\
\text { Conclusion: When } P T=4 \mathrm{~cm} \text {, then the triangle } T R U \text { has a } \\
\text { minimum area. The minimum area is } 16 \mathrm{~cm}^{2} \text {. }
\end{array}
\end{aligned}
$$

Figure 3. Solution to Problem 1 


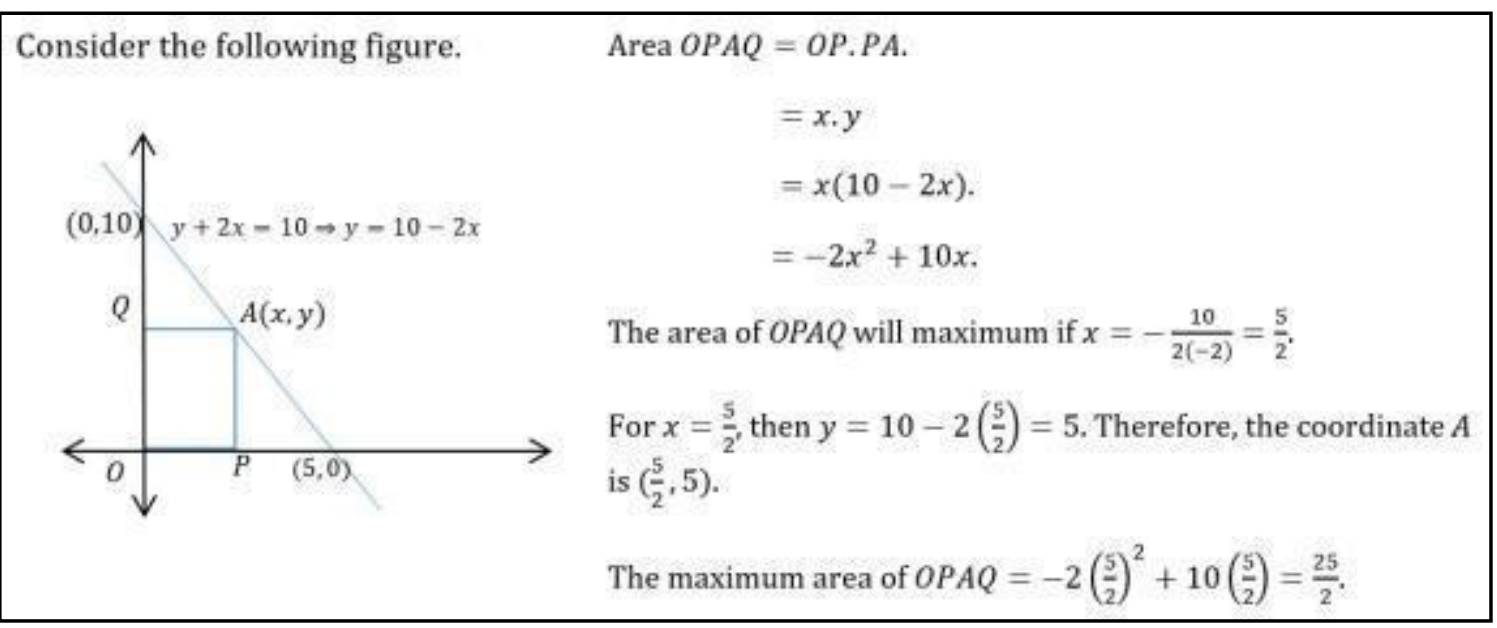

Figure 4. Solution to Problem 2

Based on the description of the classroom observation above, it can be summarized that the sequence of the teaching and learning process carried out by the lecturer is as follows. It start from reminding the concepts, principles, and formulas related to quadratic function that can be used for solving maximum and minimum problems; to explaining the application of the concepts, principles, and formulas for solving maximum or minimum problems through an example; to doing classroom discussions; and to conducting a written assessment. Considering this teaching and learning steps, which start from general ideas about concepts and principles of the quadratic function to more specific ideas of applications, we view that the lecturer uses a deductive approach in the teaching and learning process (Bahri et al., 2017; Prince \& Felder, 2006; Wardani \& Kusuma, 2020). A positive point that we obtain from this observation concerns the involvement of students in the learning and teaching process. That is, even if the lecturer used the deductive approach, which is commonly used in higher education (Jupri \& Herman, 2017; Ramsden, 1987) and recognized as teacher-centered approach, still the lecturer involved students during the explanation of the solution process. This means that the students were encouraged to actively participate and contribute during the teaching and learning process.

Another note concerns the emergence of mathematization activity during the explanation of example and during the classroom discussion. Even if it is not explicitly stated, as can be seen in Figures 3 and 4, the cycle of mathematization appeared quite clearly in the solution process. It starts from transforming the problem situation into a mathematical model to mathematical solution, and to reinterpretation of the solution into original problem (De Lange, 2006; Jupri \& Drijvers, 2016; Treffers, 1987).

\section{Analysis of written work on solving a maximum or minimum problem}

In the individual written assessment after the teaching and learning process, students of mathematics education were required to solve a minimum or maximum problem (Problem 3) shown in Figure 5. In this problem, they are required to decide whether the problem concerns a minimum or maximum problem before finding minimum or maximum value of the area. In addition, information and known data from the problem are using generalized values rather than numerical specific values. Therefore, in our view, this problem is more challenging than the problems in the teaching and learning process. 
Problem 3. Let $A B C$ be an isosceles triangle, where $A C=B C$. On this triangle, a rectangle $P Q R S$ is
constructed so that $P Q$ coincides $A B$, point $R$ on $B C$ and point $S$ on $A C$. If $A B=p$ and $C D=t$, where $C D$
is perpendicular to $A B$, then determine the length and width of the $P Q R S$ so it has maximum or
minimum area! (Just specify one: maximum or minimum area, then give an explanation.) Next,
determine the maximum or minimum area of the $P Q R S$ and give reasons for your answer.

Figure 5. Problem given to students in the written assessment

From the analysis of students' written work, we found that only 2 out of 19 students of prospective mathematics teachers could solve the Problem 3 correctly, while the rest provided incorrect answers. Figure 6 presents an example of students' written work with a correct solution and its corresponding translation of Indonesian words into English. From the perspective of mathematization, this written work shows relatively clear steps for parts of mathematization cycle (De Lange, 2006; Jupri \& Drijvers, 2016), i.e., subsequently showing a transformation from the problem to a visual geometric representation and to a mathematical model as well as to the solution process of the model within the world of mathematics. However, the step of reinterpretation or conclusion of the mathematical solution into an original problem is not clearly stated. The conclusion should be, for instance, that the problem concerns a maximum problem, and the length as well as the width that cause the maximum area of the rectangle $P Q R S$ are $p / 2$ and $t / 2$ respectively.The step of concluding through interpreting the solution of a mathematical model into the original problem, which is important in the mathematization process, in the literature is similar to the step of looking back in the Polya's model of problem solving (Polya, 1945).

Figure 7 presents examples of students' written work illustrating difficulties encountered by 17 students when constructing mathematical models from the given problem. Figure 7(a) shows the difficulty of constructing model because the student was trapped with the use of Pythagoras theorem only which does not lead to an expected mathematical model. Figure 7(b) reveals the difficulty of constructing model because of a mistake in assuming the width of the rectangle $P Q R S$, and as a consequence leading to an incorrect mathematical model. From other students' written work, difficulties of constructing mathematical models-including constructing appropriate visual representations - might be caused by, for instance, inability to recognize similarities of triangles from the visual representation that they made. These difficulties in constructing mathematical models are in line with the finding from the learning and teaching observation described in the previous sub-section and other relevant studies for prospective mathematics teachers (Jupri \& Syaodih, 2016; Malambo, 2020; Marban \& Sintema, 2020). From the perspective of mathematization, difficulties concerning transformation of a problem into a mathematical model is called the difficulties in horizontal mathematization (De Lange, 2006; Freudenthal, 1991;Treffers, 1987; Van den Heuvel-Panhuizen, 2003). In line with other relevant studies, the findings on student difficulties in constructing mathematical models (Jupri \& Drijvers, 2016; Jupri \& Syaodih, 2016) were also experienced by prospective mathematics teachers. 

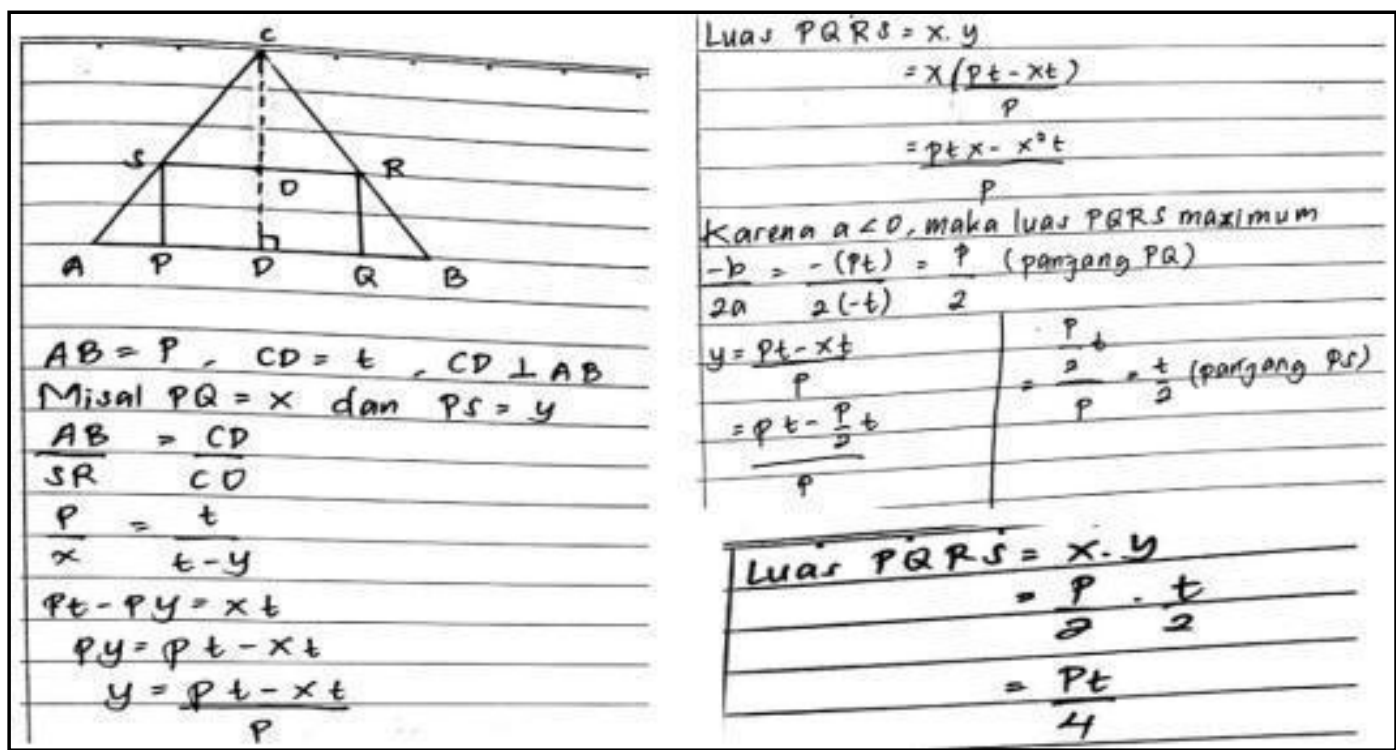

Translation of words: Misal (Let); dan (and); Luas (Area); Karena (Because); Panjang (Length)

Figure 6. An example of correct solution to the Problem 3

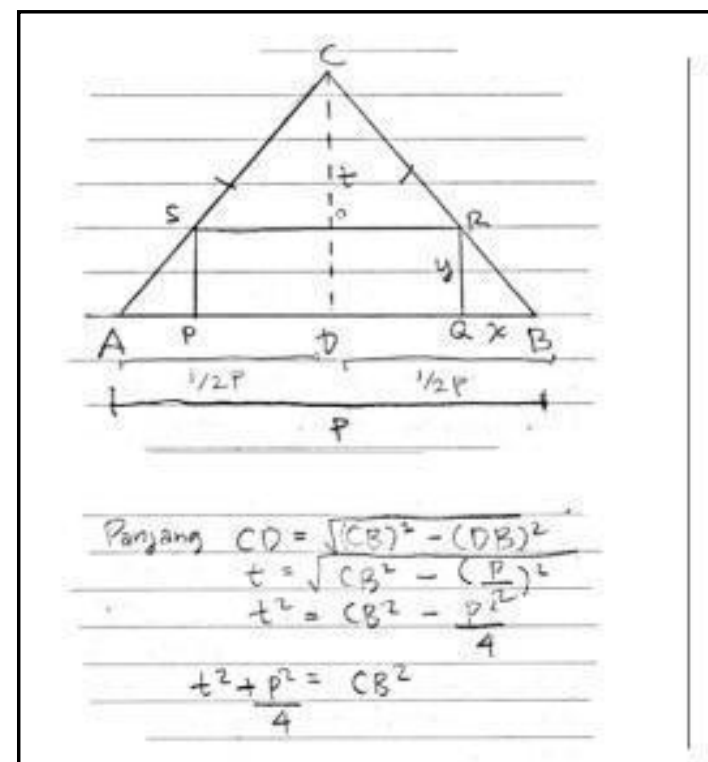

(a)

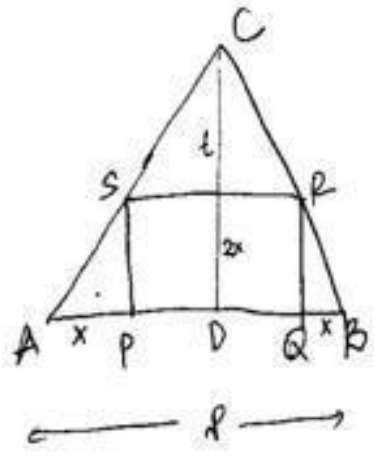

lug $P Q R S=P Q \cdot Q R$

$=(p-2 x) \cdot(t-2 x)$

$=p t-2 p x-2 t x+4 x^{2}$

Figure 7. Examples of difficulties on Problem 3 when constructing models: (a) Trapped by the use of Pythagoras theorem; (b) Incorrect assumption of the width of $P Q R S$

\section{Conclusion}

From the description in the results and discussion section, we draw the following two conclusions. First, the observed teaching and learning process of the Essential Concept of School Mathematics course for the case of solving minimum and maximum problems mainly uses the deductive teaching and learning approach. This approach follows a deductive thinking, that is, the teaching sequence that starts from more general ideas, such as explaining concepts, principles and formulas, to more specific cases including giving examples and explanations. Even if this approach seems oriented to teacher-centered 
approach, the lecturer in this course has involved students through questions and answers during the explanation process and classroom discussion. This means the deductive approach has been combined with the strategy of activating students in the learning process. An important note for improving the teaching and learning process is that the students seem to encounter difficulties following the lecturer guidance particularly in constructing mathematical models from the given problems. Considering this finding, for further research, we suggest to investigate the use of teaching approaches that provide more opportunities to students of prospective mathematics teachers to think deeper and better in constructing mathematical models. The use of Realistic Mathematics Education (RME) approach, with its inductive and explorative characters, seems appropriate to be explored in future research.

Second, the finding of difficulties in constructing mathematical models from the given maximum or minimum problems shows that the students of mathematics education program as prospective mathematics teachers lacked of ability in mathematization and horizontal mathematization in particular. For further research, an investigation of the impact of the use of inductive and explorative approaches, such as the use of an RME approach, toward students' ability in mathematization, either horizontal or vertical mathematization, seems important and relevant. Through this way, the prospective mathematics teachers will have experiences on how to learn essential concepts and problem solving skills of school mathematics using approaches having inductive and explorative characters, which in turn will be useful for their future careers as mathematics teachers.

Regardless the conclusion above, this study has several limitations. First, as the number of students involved in this study is limited, we could not make any generalization about prospective mathematics teachers' ability in dealing with maximum and minimum problems through mathematization activities. Second, as this qualitative study depends on data of observation, field notes, teaching documents, and students' written work, the data triangulation seems rather weak as there is no interview data collected. Therefore, for future research, data triangulation can be improved through collecting interview data. In this way, more comprehensive results on prospective mathematics teachers' ability in dealing with word problems will be obtained. The results of this further study in turn might contribute to the improvement of teaching and learning processes for prospective mathematics teachers.

\section{Acknowledgment}

This study was funded by Deputi Bidang Penguatan Riset dan Pengembangan, Kementerian Riset dan Teknologi/Badan Riset dan Inovasi Nasional, Republik Indonesia through Skema Penelitian Dasar, year 2020. We thank students of prospective mathematics teachers at the Department of Mathematics Education, Universitas Pendidikan Indonesia, for their active participation.

\section{Bibliography}

Bahri, S., Abrar, A. I. P., \& Angriani, A. D. (2017). Perbandingan metode deduktif dengan induktif terhadap hasil belajar matematika ditinjau dari motivasi belajar siswa. MaPan: Jurnal Matematika dan Pembelajaran, 5(2), 201-215. https://doi.org/10.24252/mapan.v5n2a4 
Bukova-Güzel, E. (2011). An examination of pre-service mathematics teachers' approaches to construct and solve mathematical modelling problems. Teaching Mathematics and its Applications: An International Journal of the IMA, 30(1), 19-36. https://doi.org/10.1093/teamat/hrq015

Chapman, 0. (2006). Classroom practices for context of mathematics word problems. Educational Studies in Mathematics, 62(2), 211-230. http://doi.org/10.1007/s10649$\underline{006-7834-1}$

De Lange, J. (2006). Mathematical literacy for living from OECD-PISA perspective. Tsukuba Journal of Educational Study in Mathematics. Vol. 25. Special Issue on The APECTSUKUBA International Conference "Innovative Teaching Mathematics through Lesson Study" (pp. 13-35). Tokyo, Japan: University of Tsukuba. Retrieved from http://www.human.tsukuba.ac.jp/ mathedu/2503

Doorman, L. M., \& Gravemeijer, K. P. E. (2009). Emergent modeling: Discrete graphs to support the understanding of change and velocity. ZDM, 41(1-2), 199-211. https://doi.org/10.1007/s11858-008-0130-z

Freudenthal, H. (1991). Revisiting mathematics education: China lectures. Dordrecht: Kluwer Academic Publishers. https://doi.org/10.1007/0-306-47202-3

Gravemeijer, K., \& Doorman, M. (1999). Context problems in realistic mathematics education: A calculus course as an example. Educational studies in mathematics, 39(1), 111-129. https://doi.org/10.1023/A:1003749919816

Jupri, A., \& Drijvers, P. (2016). Student difficulties in mathematizing word problems in algebra. Eurasia Journal of Mathematics, Science, and Technology Education, 12(9), 2481-2502. https://doi.org/10.12973/eurasia.2016.1299a

Jupri, A., \& Syaodih, E. (2016). Between formal and informal thinking: The use of algebra for solving geometry problems from the perspective of Van Hiele theory. Jurnal Pengajaran Matematika dan Ilmu Pengetahuan Alam, 21(2), 1-7. https://doi.org/10.18269/jpmipa.v21i2.817

Jupri, A. (2017). From geometry to algebra and vice versa: Realistic mathematics education principles for analyzing geometry tasks. In AIP Conference Proceedings (Vol. 1830, No. 1, pp. 050001-1-05001-5). AIPPublishing. https://doi.org/10.1063/1.4980938

Jupri, A., \& Herman, T. (2017). Theory and practice of mathematics teacher education: An explorative study at the department of mathematics education, Indonesia University of Education. In Proceedings ofInternational Conference on Mathematics and Science Education.Atlantis Press. https://doi.org/10.2991/icmsed-16.2017.38

Jupri, A., \& Rosjanuardi, R. (2020). An investigation of master student understanding on mathematical literacy problems. Jurnal Gantang, 5(1), 1-7. https://doi.org/10.31629/ig.v5i1.1828

Malambo, P. (2020). Pre-service mathematics teachers' nature of understanding of the tangent function. JRAMathEdu Uournal of Research and Advances in Mathematics Education), 5(2), 105-118. https://doi.org/10.23917/jramathedu.v5i2.10638

Marbán, J. M., \& Sintema, E. J. (2020). Pre-service secondary teachers' knowledge of the function concept: A cluster analysis approach. JRAMathEdu (Journal of Research and $\begin{array}{llll}\text { Advances in } \quad \text { Mathematics } & \text { 38ducation), }\end{array}$ https://doi.org/10.23917/jramathedu.v5i1.9703

Ndemo, Z., Zindi, F., \& Mtetwa, D. (2017). Mathematics undergraduate student teachers' conceptions of guided inductive and deductive teaching approaches. Journal of Curriculum and Teaching, 6(2), 75-83. https://doi.org/10.5430/ict.v6n2p75 
Osana, H. P., \& Royea, D. A. (2011). Obstacles and challenges in preservice teachers' explorations with fractions: A view from a small-scale intervention study. The Journal $\begin{array}{llll}\text { of } \quad \text { Mathematical 30(4), 333-352. } & \text { Behaver }\end{array}$ https://doi.org/10.1016/j.jmathb.2011.07.001

Polya, G. (1945). How to solve it: A new aspect of mathematical method. Princeton University Press. https://doi.org/10.2307/i.ctvc773pk

Prince, M.J., \& Felder, R.M. (2006). Inductive teaching and learning methods: Definitions, comparisons, and research bases. Journal of Engineering Education, 95(2), 123-138. https://doi.org/10.1002/j.2168-9830.2006.tb00884.x

Ramsden, P. (1987). Improving teaching and learning in higher education: the case for a relational perspective. Studies in Higher Education, 12(3), 275-286. https://dx.doi.org/10.1080/03075078712331378062

Rizta, A., \& Antari, L. (2019). Tingkat mathematics anxiety pada mahasiswa calon guru $\begin{array}{llll}\text { matematika. Jurnal Pendidikan } & \text { Matematika, }\end{array}$ https://doi.org/10.22342/ipm.13.1.6827.9-20

Treffers, A. (1987). Three dimensions. A model of goal and theory description in mathematics instruction-The Wiskobas project. Dordrecht, the Netherlands: Kluwer Academic Publishers. https://doi.org/10.1007/978-94-009-3707-9

Van den Heuvel-Panhuizen, M. (2003). The didactical use of models in realistic mathematics education: An example from a longitudinal trajectory on percentage. $\begin{array}{llll}\text { Educational studies in } & \text { Mathematics, }\end{array}$ http://doi.org/10.1023/B:EDUC.0000005212.03219.dc

Van den Heuvel-Panhuizen, M., \& Drijvers, P. (2020). Realistic Mathematics Education. In: Lerman S. (eds) Encyclopedia of Mathematics Education. Springer, Cham. https://doi.org/10.1007/978-3-030-15789-0 170

Verschaffel, L., Schukajlow, S., Star, J., \& Van Dooren, W. (2020). Word problems in mathematics education: a survey. ZDM Mathematics Education, 52, 1-16. http://doi.org/10.1007/s11858-020-01130-4

Wardani, S., \& Kusuma, I. W. (2020). Comparison of learning in inductive and deductive approach to increase student's conceptual understanding based on international standard curriculum. Jurnal Pendidikan IPA Indonesia, 9(1), 70-78. https://doi.org/10.15294/jpii.v9i1.21155

Yilmaz, S., \& Tekin-Dede, A. (2016). Mathematization competencies of pre-service elementary mathematics teachers in the mathematical modelling process. International Journal of Education in Mathematics, Science and Technology, 4(4), 284298. https://doi.org/10.18404/ijemst.39145 